\title{
Characterization of pre- and postharvest losses of tomato supply chain in Ethiopia
}

\author{
Bezabih Emana ${ }^{1}$, Victor Afari-Sefa ${ }^{2 *} \mathbb{0}$, Ngoni Nenguwo $^{3}$, Amsalu Ayana $^{1}$, Dereje Kebede ${ }^{1}$ \\ and Hedija Mohammed ${ }^{1}$
}

\begin{abstract}
Background: Tomato has significant economic importance in Ethiopia. Although quantitative evidence is limited, postharvest loss in tomato is considerably high. This study presents qualitative and quantitative postharvest losses of tomato. The study was conducted in 2015 in two districts (Bora and Dugda) located in East Shewa Zone of Oromia National Regional State, Ethiopia, located southeast of Addis Ababa. Primary data were collected from producers (smallholder farmers) and traders via household survey, focus group discussions and key informant interviews as well as estimation of losses based on samples. Secondary data and information were collected from published and unpublished sources.
\end{abstract}

Results: Results indicate that tomato production is being done by relatively young married individuals who have at least primary level education. About three-quarter of land holding is allocated for vegetable production, which largely takes place under irrigation during dry season. All sample producers sold more than $95 \%$ of their tomato produce, mostly to wholesalers as compared to collectors and retailers. Postharvest losses occur at collectors, wholesalers and retailers level. The finding indicates that more than $16 \%$ of respondents encounter produce losses due to high incidence of diseases, insect pest and mechanical injuries, each of them accounting for more than $20 \%$ of postharvest losses.

Conclusions: The findings from our study underscore that the ability of actors to mitigate postharvest losses is limited due to lack of technical know-how. They also lack necessary support and complementary resources to improve postharvest handling practices and technology.

Keywords: Postharvest management, Produce shelf life, Value chain analysis, Vegetable marketing, Vegetable production

\section{Background}

In Ethiopia, the vegetable subsector has a vital role in human nutrition and health, farm income generation, poverty alleviation and foreign currency earnings through export and foreign direct investment $[2,5,10]$. Processed products such as tomato paste and tomato juice are produced for export to Somalia, Djibouti and Saudi Arabia, making a significant contribution to the national economy [3, 6]. Ethiopia's wide range of agroclimatic conditions and soil types makes it suitable for

\footnotetext{
*Correspondence: victor.afari-sefa@worldveg.org

${ }^{2}$ World Vegetable Center, West and Central Africa, Samanko Research

Station, PB 320, Bamako, Mali

Full list of author information is available at the end of the article
}

the production of both warm and cool season vegetables $[7,29]$. Vegetable crops are suitable for production under intensive systems, where some farmers produce two to three times within a calendar year in Ethiopia [8]. However, vegetable production in the country is constrained by several challenges [5, 9]. Among them, postharvest loss of vegetables such as tomato is of critical importance [30, 37-39].

Postharvest losses (PHL) refer to the losses that occur along the food supply chain, from the farm gate through till it gets on the table of the final consumer. Losses are encountered along the chain in the handling, storage, transportation and processing, thereby resulting in a reduction in the quantity, quality and market value of 
agricultural commodities [4, 19, 27]. Within developing countries' context and in Ethiopia particularly, concerns about reduction of quantitative losses (i.e., weight, volume or total wastage of agricultural produce) are of higher priority than qualitative losses such as loss in edibility, nutritional quality, caloric value and consumer acceptability of the produce. It is also known that, in general, qualitative losses are much more difficult to assess than quantitative losses.

The main causes of postharvest losses include mechanical damage, physiological deterioration and biological (i.e., postharvest diseases and insect pests) $[1,11,19,26$, 27, 32]. Rodents and birds also cause postharvest losses, especially in fruits such as tomatoes [17], although such losses tend to be relatively small for vegetables compared to damages due to rough handling, poor packaging and quality losses caused by temperature stress [35]. In some cases, postharvest losses of vegetables such as tomato are also attributed to socioeconomic and institutional factors, viz. inadequate marketing information and support systems, inappropriate transportation facilities, unfavorable government policies, inability to implement regulations and legislations, lack of appropriate tools and equipment, lack of technical know-how and poor maintenance culture for existing facilities and infrastructure $[19,28,35]$. In most developing countries such as Ethiopia, roads are not adequate for proper transport of horticultural crops, while transport vehicles and other modes, especially those suited for fresh horticultural perishables, are in short supply. Moreover, the extent of losses is significantly influenced by preharvest conditions and field operations such as cultivar and soil types, crop management practices, poor weather conditions, insect pest control programs and harvesting as well as packaging and handling practices [21].

Moreover, postharvest losses vary greatly with commodities, production areas and seasons as well as the level of development of infrastructure and technology for postharvest management and market system $[15,18-20$, 22, 23]. Vegetable postharvest loss in Ethiopia could be as high as $40 \%$. However, quantitative and qualitative assessment information of postharvest losses of vegetables in Ethiopia remains scarce and is mostly based on guess estimates [30, 37-39] as opposed to formal quantitative field surveys. Despite the rich knowledge of postharvest losses in tomato production and marketing in the world, there is huge knowledge gap in postharvest handling and management in Ethiopia. The extent of losses is also not known with reasonable accuracy. There exists only little recent quantitative and systematic evidence on the magnitude of postharvest losses in tomato production and marketing in Ethiopia [16, 30]. Even so, these studies mostly considered a range of horticultural crops that exclude tomato. The objective of this paper therefore is to generate country-specific knowledge in tomato regarding the production system, postharvest management and losses and analyze the factors responsible for such observed losses. The remaining part of the article describes the study area and methodology, key findings of the study and conclusions that trigger policy interventions.

\section{Methods}

\section{Description of the study area}

The study was conducted in two districts (Bora and Dugda) located in East Shewa Zone of Oromia Regional State, located southeast of Addis Ababa, Ethiopia (Fig. 1). In 2013, the population of the two districts was 236,794 of which $48.4 \%$ was female. About $25 \%$ of the population lives in towns. Geographically, the study districts are located from $8^{\circ} 00^{\prime} 00^{\prime \prime}$ to $8^{\circ} 25^{\prime} 00^{\prime \prime}$ east and from $38^{\circ} 30^{\prime} 00^{\prime \prime}$ to $39^{\circ} 50^{\prime} 00^{\prime \prime}$ north. The districts are located in the Rift Valley, where major vegetables such as tomato, onion and leafy vegetables like kales are produced primarily for the market. The districts are known for their good road network and other basic infrastructure such as transport, telecommunication and electricity. They are also well connected to major market areas like Addis Ababa, Adama, Hawassa, Shashemene and Bishoftu. Intensive small-scale farming is practiced whereby farmlands are used for 2-3 times per year for vegetable production under both rain-fed and irrigated conditions.

The study area also shares major challenges faced by vegetable producers in the country. The challenges include lack of capacity in terms of knowledge and skill gap for postharvest loss management and limited access to viable produce markets.

\section{Data collection and analysis}

Data for the study were collected from primary and secondary sources in December, 2014. Secondary data and information were collected from desk reviews and unpublished raw data collected from the Central Statistical Agency (CSA). Primary data were collected from producers (smallholder farmers) and traders via one-on-one survey (producers and traders), focus group discussions (FGD) and key informant interviews. The producers' survey covered five sampled kebeles ${ }^{1}$ involving 155 sample households drawn from both districts, while the traders' survey covered 56 traders -29 wholesalers, 5 collectors and 22 retailers. The sampled producers were equally distributed among the kebeles ( 31 from each kebele), while the proportion of female farmers interviewed was $11 \%$.

\footnotetext{
${ }^{1}$ Kebeles are the lowest administrative unit below district in Ethiopia.
} 


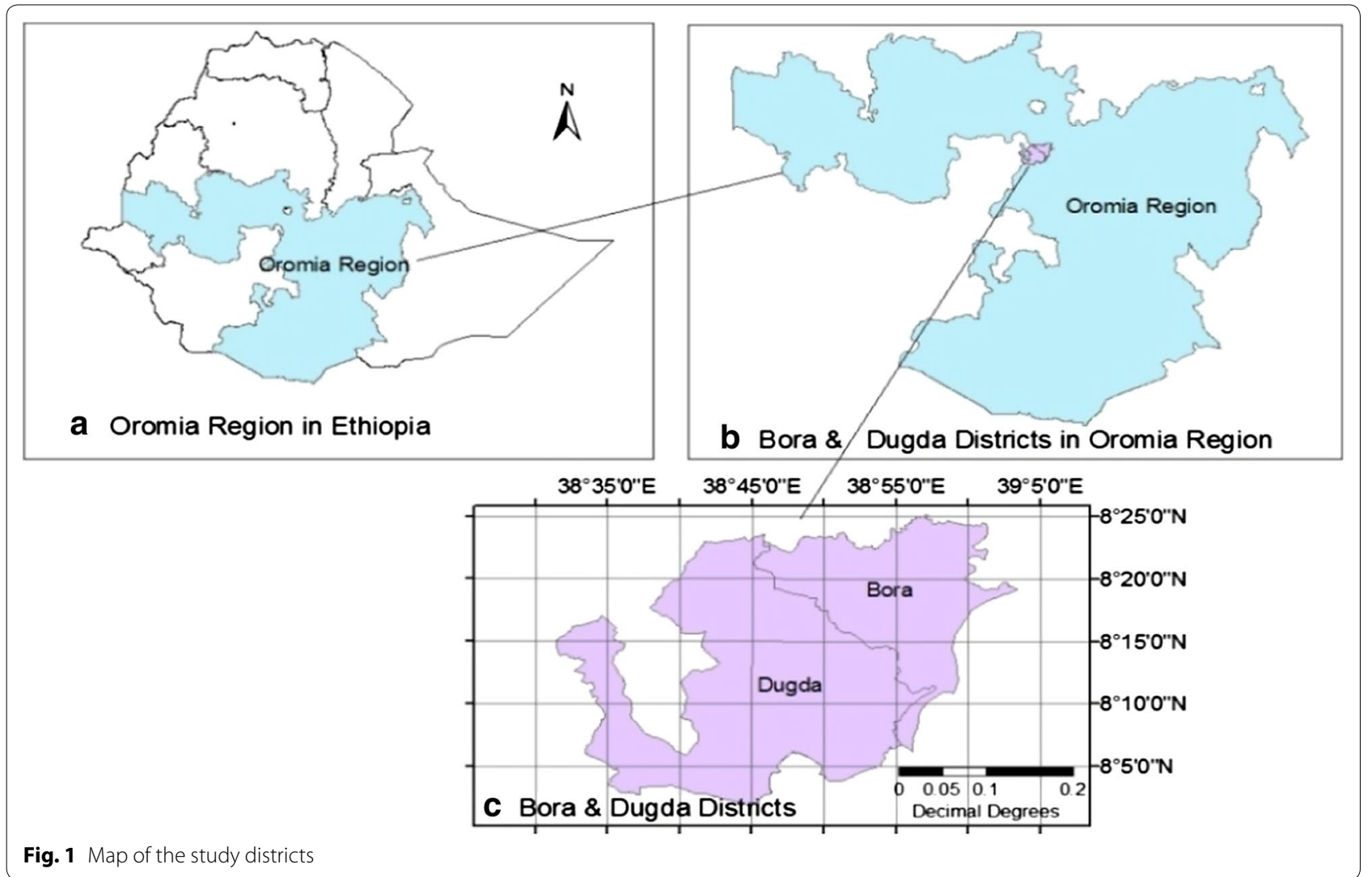

A structured questionnaire was designed and used for the one-on-one quantitative interview. The questionnaire covered diverse issues such as tomato production, produce utilization, marketing, postharvest handling, transportation, postharvest losses and its management and factors causing postharvest losses.

Moreover, a physical fresh produce quality survey was also conducted to determine the type, extent and causes of postharvest losses. In total, tomato samples were randomly collected from 45 sampled producers and traders. Two kilograms of tomato was purchased from each of the sampled respondents on a random basis. Digital weighing scales were used to measure the weight of tomatoes purchased. Damaged tomato was sorted based on physical damage, damage by diseases and insect pests, wilting, damage due to deformity or color. Sorting was made with replacement after the weight of tomato classified under a particular damage category was recorded. In addition, an MM laboratory thermometer was used to measure pulp temperature of tomato and corresponding ambient temperatures of the produce.

Moreover, information that complements quantitative data was collected through focus group discussion (FGD) with group of producers and key informants interview (KII). Two FGDs were conducted in two of the sample kebeles (i.e., one for each district with 10 producers in each kebele). Key informant interviews were also conducted with relevant district-level agriculture offices and farmers' cooperative union. In total, eight district agriculture office experts and two farmers' cooperative union representatives were interviewed as key informants in both target districts. In-depth discussion on production system, postharvest losses, and production and marketing constraints and opportunities were undertaken during the FGDs and KIIs. Moreover, horticulture experts at district and Farmers' Training Centers were interviewed as key informants on extent of tomato postharvest losses and possible causes of such losses. The primary data were augmented with secondary data collected from various publications based on national and international studies. The data collected were encoded and entered into Microsoft Excel spreadsheets and Statistical Package for the Social Science (SPSS) Software version 21 package. Data obtained from various sources were also triangulated, checked for consistency and analyzed.

\section{Results and discussion}

\section{Demographic characteristics of producers}

The demographic profiles of the sampled tomato producers are presented in Table 1 . About $47 \%$ of the sample 
Table 1 Proportion of producers by demographic profile

\begin{tabular}{ll}
\hline Category & Mean \\
\hline Average age $(N=64)$ & 33 \\
Average household size & Percent \\
\hline & \\
\hline Gender $(N=64)$ & 11 \\
Female & 89 \\
Male & \\
Marital status $(N=64)$ & 78.3 \\
Married & 18.3 \\
Unmarried & 0 \\
Divorced & 3.3 \\
Widow & \\
Educational level & 51.7 \\
Primary & 20.0 \\
Secondary & 3.3 \\
College & 25 \\
No formal education & \\
Experiences (year) $(N=56)$ & 39 \\
$<10$ & 47.5 \\
$11-20$ & 13.6 \\
$>21$ &
\end{tabular}

Source: Own Survey, 2015

producers (64 respondents) were involved in tomato production, of which $89 \%$ are males. Approximately $78 \%$ of tomato producers are married and have an average household size of 5 persons per household. Producers' age range from 20 to 67 years, with an average of 33 years implying that young cohort of farmers are more involved than elder ones in tomato production. The majority of them have less than 20 years of experiences in farming. As tomato is largely produced for the market, younger farmers tend to establish good marketing network, use market information and bear risk involved in tomato production than the elderly. Younger farmers also have better access to education with $75 \%$ of the sampled tomato producers having received formal education (primary school to college level). Education gives the farmers also to analyze the benefits, costs and risks involved in tomato production.

\section{Demographic profile of tomato traders}

Close to two-third of the respondents are male tomato traders (Table 2). Female traders are mostly involved in small vegetable retailing in urban settings. This presupposes that women do not have enough capital to engage in wholesaling of vegetables, and such business activities also involve a lot of engagement and networking, which is hard to be attained for most women traders. With regard
Table 2 Proportion of traders by demographic profile

\begin{tabular}{|c|c|c|c|}
\hline \multirow[t]{2}{*}{ Category } & \multicolumn{2}{|c|}{ Percent of traders } & \multirow[t]{2}{*}{ Total } \\
\hline & Wholesaler & Retailer & \\
\hline \multicolumn{4}{|l|}{ Gender $(N=56)$} \\
\hline Female & 3.4 & 86.4 & 37.5 \\
\hline Male & 96.6 & 13.6 & 62.5 \\
\hline \multicolumn{4}{|l|}{ Marital status $(N=56)$} \\
\hline Married & 65.5 & 59.1 & 66.1 \\
\hline Unmarried & 34.5 & 13.6 & 23.2 \\
\hline Divorced & - & 4.5 & 1.8 \\
\hline Widow & - & 22.7 & 8.9 \\
\hline \multicolumn{4}{|c|}{ Educational level of traders $(N=56)$} \\
\hline Primary & 24.1 & 36.4 & 30.4 \\
\hline Secondary & 51.7 & 18.2 & 35.7 \\
\hline College & 13.8 & - & 8.9 \\
\hline No formal education & 10.3 & 45.5 & 25 \\
\hline \multicolumn{4}{|c|}{ Experiences (in year) $(N=56)$} \\
\hline$<5$ & 64.3 & 40 & 56 \\
\hline $5-10$ & 21.4 & 30 & 23 \\
\hline$>10$ & 14.3 & 30 & 21 \\
\hline \multicolumn{4}{|c|}{ Average household size (mean value) } \\
\hline & 4.5 & 4.5 & 5 \\
\hline
\end{tabular}

Source: Own Survey, 2015

to marital status, most of the vegetable traders are married and have an average household size of five. Vegetable collectors are few ( $2 \%$ of the sampled traders), indicating that the wholesalers are also involved in purchasing vegetables at farm gate. Interestingly, $75 \%$ of the sampled vegetable traders have attained formal education (primary school to college level) showing that the vegetable trading is quite attractive to educated people, partly as it provides opportunities for educated people and partly because educated farmers see the attractiveness of trade business.

\section{Tomato production}

Vegetable production including tomato is largely practiced under irrigation using water pumped from nearby lakes and from over 5000 shallow wells dug for irrigation. Based on information elicited from the KIIs, 15,547 rural households are engaged in irrigated production of vegetables in the study districts. More than $90 \%$ of these households use irrigation for vegetable production. Similarly, the survey findings indicate that $99 \%$ of the vegetable producers practice irrigated farming, while $34 \%$ produce vegetables under rain-fed conditions, with no significant difference between the two districts. The FGD results also show that tomato is preferably produced during the dry season under irrigation mainly to reduce risks of diseases and insect pests. Irrigated production of vegetables including tomato is undertaken twice a year, from 
January to June with irrigation only and from September to December with supplementary irrigation.

Tomato is a major vegetable grown in the study area with the survey results indicating that about $47 \%$ of the sampled farmers produce tomato. The survey result also indicates that households on the average allocate around $44 \%$ of their farmland ( $0.74 \mathrm{ha})$ for tomato production. The total output per household is about 24 tons per season. The average yield of tomato is 39.8 tons/ha showing considerable variability between sampled farmers. The productivity of tomato at farm-gate level is fairly comparable with yield potential under research field for tomato in Ethiopia [12]. Based on the area allocated for tomato production and the average yields, the total supply of the produce from the two districts was estimated at 387,567 tons per annum.

\section{Marketing of tomato}

As it is indicated earlier, a significant proportion of the tomato harvest are meant for sales in various cities/towns within Ethiopia, implying that production of the crop is commercially driven and access to market is crucial to improve household incomes. The survey results indicate that about $98 \%$ of tomato was sold during the last production season. The remaining $2 \%$ was used for different purposes, including family consumption and gift to neighbors. The tomato supplied to the market is also subjected to quality and quantity loss, as also discussed in the subsequent sections.

Farmers have various marketing channels through which they sell their produce. As shown in Fig. 2, farmers can sell tomato to village collectors, wholesalers, retailers, cooperatives and consumers. Sales to wholesalers account for significant share of tomato, accounting for 93\% of tomato sold by the producers.

Village collectors and cooperatives buy very small proportion of the produce. Some farmers especially women also sell small quantities of tomato in the open market to consumers. However, the FGDs results indicate that producers have limited access to wholesalers. The transaction to wholesalers is exclusively through brokers who play a dominant role in facilitating trade between producers and wholesalers. They link the wholesalers to the producers at farm gate or local wholesalers who operate at smaller scale to larger wholesalers in other cities/towns. Only $10-15 \%$ of producers sell the produce through retailers, and fewer farmers sell through other lesser known channels. Not surprisingly, the quantity of tomato sold through these channels is smaller (5\%).

Moreover, the survey results indicate that the majority of the urban collectors or local wholesalers supply to the larger wholesalers coming from other towns (83\%) and are often called gap fillers. More than $40 \%$ of them also sell to urban small retailers. The result indicates that all wholesalers in main cities are registered companies, while the majority of the urban collectors/local wholesalers are informal and not registered as a trade company. This implies that the majorities of these traders are not recognized and lack access to requisite institutional support.

Unlike most producers, the majority of fruits and vegetable traders are simultaneously involved in handling different types of vegetables and rarely specialize in a particular commodity (Table 3 ) with the aim to diversify the fresh produce they handle so as to maximize their returns and reduce losses. This approach to vegetable trading is practiced by wholesalers and retailers alike though retailers diversify more than wholesalers. The survey result shows that tomato traders also handle onion and some of them handle kales and hot peppers. Some retailers also trade in potato and garlic, so that the consumers who purchase these produce in smaller quantities are able to source all their supplies from one location. It is, however, important to note that vegetable and fruit traders do usually handle other food commodities such as cereals which have distinct features.

Vegetable trading in the study area is largely informal. Despite the policy that requires registration of business and the need for a valid trade license, only $17.2 \%$ of the sampled wholesalers reported to have business license, while all the retailers do not possess one. Tomato marketing/trading is done in collaboration with brokers and other traders, who are not also licensed, hence making accountability for their marketing or service behavior more challenging. Collaboration can be between traders of the same category where wholesalers collaborate with other wholesalers or with other categories where wholesalers collaborate with collectors, broker or retailers. However, such collaboration involved each a maximum of two brokers/commission agents, wholesalers or retailers. The means of such collaboration largely include sharing with each other market information and even to some extent supply of vegetables to the collaborator when there is supply shortage (Fig. 3).

Membership into an association or traders group also helps for systematic networking of the trade business by improving social capital. However, only $9 \%$ of the traders belong to trade associations or groups relevant to their business undertakings (Table 4). This may limit their access to necessary services such as credit and joint transportation services as well as voicing their needs to policy and decision makers in the government administration. The size of associations to which the wholesalers belong to is significantly larger than that of the retailers. 


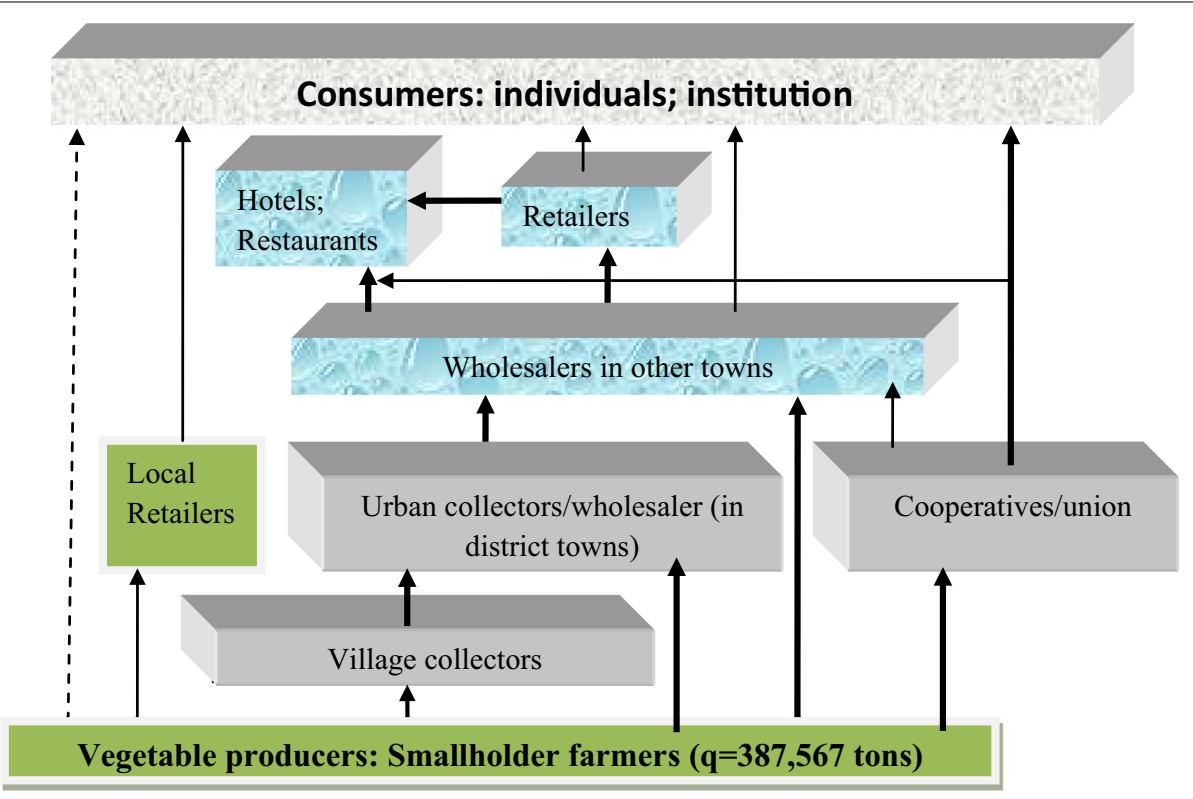

Fig. 2 Tomato marketing channel

Table 3 Proportion of traders by their main trading activities (\%)

\begin{tabular}{lllll}
\hline Fresh produce & Collectors & Wholesaler & Retailer & Total \\
\hline Tomato & 100 & 79.3 & 59.1 & 64.3 \\
Onion & 40 & 79.3 & 68.2 & 67.9 \\
Kale & & 6.9 & 40.9 & 19.6 \\
Hot pepper & & 13.8 & 18.2 & 14.3 \\
Green bean & & 6.9 & - & 3.6 \\
Potato & & - & 18.2 & 7.1 \\
Garlic & 5 & 34 & 4.5 & 1.8 \\
N & 5 & 22 & 56 \\
\hline
\end{tabular}

Source: Own Survey, 2015

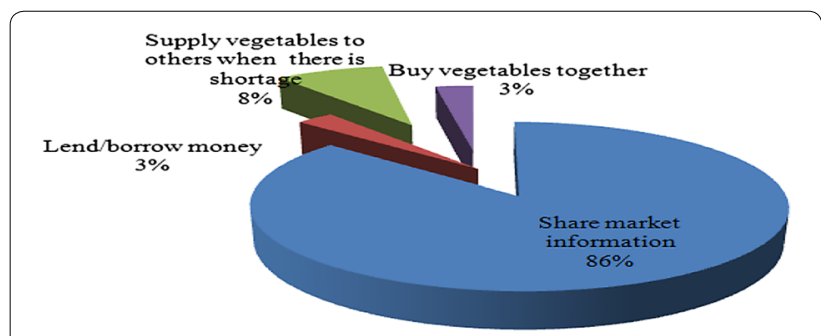

Fig. 3 Means of collaboration of tomato traders with each other

\section{Tomato price determination}

Tomato traders buy tomato from different sources and sell to different buyers. Just considering the producer, collector, wholesaler, retailer and consumer produce flow
Table 4 Traders by some features of their tomato business

\begin{tabular}{llll}
\hline Trader & Collectors & Wholesaler & Retailer \\
\hline Licensed (\%) & 0 & 17.2 & 0 \\
Member of associations (\%) & 20 & 7.4 & 9.1 \\
Size of association (\# of members) & 4 & 118 & 22 \\
Collaborating with brokers (\%) & 80 & 82.8 & 18.2 \\
Collaborating with retailers (\%) & - & 72.4 & 45.5 \\
Collaborating with wholesalers (\%) & 60 & 79.3 & 22.7 \\
$N$ & 5 & 34 & 22 \\
\hline
\end{tabular}

Source: Own Survey, 2015

channel, the buying and selling prices of the traders are given in Table 5 . The buying price of collectors represents the selling price of the producers, while the selling price of the retailer represents the consumer price. Brokers press producers to reduce price. When the tomato crop is ready for harvest in many fields at the same time, the producers become price takers and sell it at whatever price could be offered by the traders rather than negotiating for higher prices, due to the perishable nature of the produce. The survey result reveals that actors along the value chain handle tomato of different qualities. The traders sort tomato every time they handle it. Good-quality tomato is sold to larger wholesalers coming from other cities/towns, while low-quality tomato is sold to retailers at lower prices. The wholesalers face less price reduction for tomato because they trade in relatively high-quality fresh produce in comparison with retailers and hence attract higher margins. 
Table 5 Average buying and selling prices of tomato in the study districts $(E T B / 100 \mathrm{~kg})$

\begin{tabular}{llll}
\hline Trader & Buying & Selling & Trader's margin \\
\hline Collector $(N=5)$ & 440 & 560 & 120 \\
Wholesaler $(N=34)$ & 518 & 678 & 159 \\
Retailer $(N=22)$ & 365 & 463 & 98 \\
\hline
\end{tabular}

Source: Own Survey, 2015

\section{Postharvest handling of tomato}

With regard to transport, some vegetable traders use cart to transport the produce directly from the field/farm to their business center, while others engage the services of suppliers to bring the produce to their place. Collectors used only vehicles and animal-drawn carts, while retailers used animal-drawn carts and human labor to transport tomato. Wholesalers use different means of transportation (Table 6).

Vegetable traders, who do not transport the product directly from field/farm to their business center, receive the produce from their suppliers/partners transported to their business area. Most of the collectors and retailers receive the produce transported by the sellers. The suppliers used different modes of transport to bring tomato to the buyers. Vehicles (own and rented) are the most common means of transport followed by animal-drawn cart used by suppliers to deliver tomato to collectors and wholesalers. Retailers receive tomato transported by human and carts only.

Produce from the farm gate is mostly packed and delivered in wooden boxes (Table 7). Insulated Styrofoam boxes and airtight plastic packing materials were not known as containers used for delivery by the respondents involved in this study.

In terms of storage, about $37 \%$ of the traders used rented premises to store tomato and other vegetables they handle (Table 8). However, in most cases, tomato is highly perishable and about $42 \%$ of the traders sell it immediately as they received.

Table 6 Proportion of traders by how they transport vegetables (\%)

\begin{tabular}{llll}
\hline $\begin{array}{l}\text { Means of transporting pur- } \\
\text { chased tomato by buyer }\end{array}$ & Collectors & Wholesaler & Retailer \\
\hline Hand cart & - & 11.1 & - \\
Vehicle & 40.0 & 61.1 & - \\
Pickup truck & - & 11.1 & - \\
Animal-drawn cart & 60.0 & 11.1 & 66.7 \\
Public transport & - & 5.6 & - \\
Manual labor & - & - & 33.3 \\
$N$ & 5 & 34 & 22 \\
\hline
\end{tabular}

Source: Own Survey, 2015
Table 7 Traders stating the form the incoming produce is delivered to their business center (\%)

\begin{tabular}{llll}
\hline Form of deliver & Collector & Wholesaler & Retailer \\
\hline Plastic bag & - & - & 9.1 \\
Sacks & - & - & 18.2 \\
Wooden boxes & 100.0 & 88.9 & 81.8 \\
Bamboo basket & - & - & 9.1 \\
Loose & - & 5.6 & - \\
N & 5 & 24 & 22 \\
\hline
\end{tabular}

Source: Own Survey, 2015

Table 8 Proportion of traders by where they store tomatoes (\%)

\begin{tabular}{llc}
\hline Place of storage & No & Tomato \\
\hline Own storage & 3 & 9.7 \\
Rented storage & 14 & 38.7 \\
Cooperative's storage place & 3 & 9.7 \\
I don't store & 14 & 41.9
\end{tabular}

Source: Own Survey, 2015

Several studies have reported high postharvest losses due to poor packaging, inadequate storage facilities and poor means of transportation using human labor, donkeys and mules, public transport and rented trucks [14]. Such losses can be reduced by harvesting produce at optimal maturity, through grading, packaging and careful handling of the produce, maintaining higher sanitation standards, decreasing injury incidence and maintaining good storage and environmental conditions [14, 37-39]. Moreover, treatment combinations such as low temperature, waxing, low oxygen and high carbon dioxide storage and ethylene inhibitor such as calcium chloride treatment have been reported to have the potential to extend the storage life of fresh produce such as tomatoes [13]. Moreover, some literature also claims that tomatoes could be marketed at premium quality if lower storage temperatures were accessible and encouraged private sector to provide such facilities particularly in urban markets where retail prices will merit such investments. In general, maintaining appropriate storage of vegetables can minimize moisture loss and wilting, slow down respiration rate, prolong shelf life and inhibit development of decay-causing pathogens.

Postharvest loss is a key concern of the tomato value chain actors at different levels. Sample tomato producers were asked whether they faced losses during the last production season, while the traders were asked about losses encountered on a weekly basis. The results indicate that $76 \%$ of the producers and more than $60 \%$ of traders encountered physical postharvest losses in tomato marketing (Table 9). 
Table 9 Proportion of tomato value chain actors stating of tomato traded (\%)

\begin{tabular}{|c|c|c|c|c|c|}
\hline $\begin{array}{l}\text { Type } \\
\text { of trading } \\
\text { activity }\end{array}$ & No & $\begin{array}{l}\% \text { of respond- } \\
\text { ents }\end{array}$ & $\begin{array}{l}\text { Average } \\
\text { quantity } \\
\text { traded } \\
\text { (ton) }\end{array}$ & $\begin{array}{l}\text { \% loss } \\
\text { (meas- } \\
\text { ured) }\end{array}$ & $\begin{array}{l}\text { \% loss } \\
\text { (per- } \\
\text { ceived) }\end{array}$ \\
\hline Producers & 64 & 75.9 & $21.46^{* *}$ & 3.7 & 5.3 \\
\hline \multicolumn{6}{|l|}{ Traders } \\
\hline Collector & 5 & 80.0 & $2.31^{*}$ & 2.8 & 12.7 \\
\hline Wholesaler & 34 & 65.5 & $22.48^{*}$ & 3.0 & 7.2 \\
\hline Retailer & 22 & 59.1 & $0.13^{*}$ & 6.7 & 8.2 \\
\hline
\end{tabular}

* Quantity traded per week and ** Quantity sold per season

Source: Own Survey, 2015

The sample producers sold an average of about 22 tons of tomato per single production season of which $3.7 \%$ was lost due to spoilage. The result indicates about 21.46 tons of tomato was sold by the producer household to different market actors, while the remaining balance was used in different ways (consumption, gift, etc.). As it is shown in Table 9, wholesalers traded about 22.48 tons of tomato per week, while the percentage loss is more than double in the case of retailers who handle about 0.13 tons of tomato per week. Retailers buy and sell smaller quantities of tomato, hold the produce for relatively longer time and encounter larger percentage losses. Samples collected from producers and traders measured the actual level of loss due to damage and poor quality. As can be seen in Table 9, these estimated measured levels are lower than the perceived losses of producers and traders.

In order to determine the extent of losses and characterize the different types of postharvest damage on tomato, postharvest losses were measured based on real production and marketing contexts along the value chain. In total, 40 tomato samples were collected from producers and traders, characterized and measured for damages. The assessment result indicates the prevalence of various forms of damages including mechanical damage, disease and insect attack; poor shape and sun burn among others are observed along the value chain. At farm level, significant proportion of tomato damage occurred due to insect attack (26\%) and disease (25\%) (Table 10). Limited access to appropriate harvesting tools and skills as well as poor disease and insect pest control measures are the notable factors causing damage at farm level.

On the other hand, among the wholesalers, over $40 \%$ of tomato was affected by disease. Retailers were also engaged in marketing of low-quality fresh produce due to varied factors. Undesirable color and deformed shape of the produce are serious problems across the value chain. The respondents partly attributed to the poor-quality
Table 10 Percent of tomato observed having undesirable quality (physical) characteristics

\begin{tabular}{llll}
\hline Causes of poor quality & Producer & Wholesaler & Retailer \\
\hline Mechanical damage & 16.0 & 15.4 & 13.0 \\
Disease & 25.0 & 41.1 & 28.0 \\
Insect pests & 26.0 & 14.7 & 31.9 \\
Deformed shape & 14.8 & 13.5 & 13.7 \\
Sun burn & 9.5 & 8.6 & 15.8 \\
Undesired color & 24.1 & 31.5 & 31.6 \\
No & 64 & 34 & 22 \\
\hline
\end{tabular}

Source: Own Survey, 2015

tomato sold in the market along the value chain to nutrient deficiency during the plant growth.

The findings are also consistent with the findings of other authors. Hussen et al. [16] for example found out that inadequate storage and transportation facilities, diseases and insect pests are found to be significant factors contributing to postharvest losses in horticultural crops. Lack of storage facilities forces the value chain actors to dispose of tomato even if the prices are low. According to Teka [31], the farmers store tomato when the price gets low for an average of 3 days. Due to lack of well-ventilated storage facilities and adequate, reliable and timely market information, farmers are forced to dispose of their produce within a short period even if the selling price is low. Efforts made to apply modern postharvest handling practice (such as curing, grading and storing) to increase the shelf life of tomato are low [25]. Knowing this lack of ability and facilities to store tomato for long, wholesalers put pressure on producers to sell at low price.

High temperature is one of the factors for enhanced postharvest loss of tomato. The climate of most zones of Ethiopia is characterized by high ambient temperature combined with low relative humidity, which has a negative effect on tomato quality during harvesting, transportation, storage and marketing. Under such conditions, using methods such as the forced ventilation evaporative cooling system is expected to effectively reduce postharvest loss and prolong shelf life of tomato [36].

The measured pulp temperature of tomato was less than that of the corresponding average ambient temperatures (Table 11). Although the pulp temperatures for tomato were found to be lower than the corresponding ambient temperature, produce temperatures are far above the recommended temperature (e.g., $15{ }^{\circ} \mathrm{C}$ for tomato pulp temperature) [34]. It is interesting to note that the temperature does decrease from producer through to retailer (Table 11). High temperatures are well known to result in increased rates of respiration, deterioration and water loss in fresh produce, leading to reduced 
Table 11 Average ambient pulp temperature of tomato taken from actors $\left({ }^{\circ} \mathrm{C}\right)$

\begin{tabular}{llll}
\hline Temperature & Producer & Wholesaler & Retailer \\
\hline Ambient temp & 30.0 & 26.8 & 25.2 \\
Pulp temperature & 26.0 & 24.3 & 23.0 \\
N & 9 & 17 & 3 \\
\hline
\end{tabular}

Source: Own Survey, 2015

market value and decreased nutritional value [24]. It is to be noted that fresh produces such as tomato need low temperature and high relative humidity during the storage and transportation. Reduced temperature decreases physiological, biochemical and microbiological activities, which are the causes of quality deterioration such as flavor and color [14, 37-40].

Various causes of postharvest losses were identified along the value chain. The majority of producers reported diseases and insect pests as the major problems affecting their produce (Table 12), while wholesalers indicated that damage during transportation was a concern. Due to its perishable nature, tomato harvesting is time sensitive and requires intensive engagement over a short period of time. Workers that do not have adequate skills and tools are engaged in harvesting, and this has been causing significant damage to produce. Unfavorable weather conditions, during and after harvest, affects the produce quality. Damage during transport was also reported by the majority of village collectors and wholesalers. Lack of market is also reported by sizeable number of producers, collectors and retailers as a reason for produce quality deterioration. Brokers' practice of creating information symmetry aggravates the situation.

\section{Practices to reduce produce loss}

The tomato value chain actors take different measures to reduce postharvest loss or produce damage (Table 13). Producers focus on appropriate harvesting practices

Table 12 Proportion of value chain actors stating reasons for loss of tomato (\%)

\begin{tabular}{llll}
\hline Reason & $\begin{array}{l}\text { Producers } \\
(\mathbf{N = 4 4 )}\end{array}$ & $\begin{array}{l}\text { Wholesaler } \\
(\mathbf{N = 2 9 )}\end{array}$ & $\begin{array}{l}\text { Retailer } \\
(\mathbf{N = 2 2})\end{array}$ \\
\hline $\begin{array}{l}\text { Unfavorable weather } \\
\quad \text { condition }\end{array}$ & 9.1 & 20.6 & 13.6 \\
$\begin{array}{l}\text { Disease and pests } \\
\text { Damage during harvest }\end{array}$ & 61.4 & 20.7 & 22.7 \\
$\begin{array}{l}\text { Delay of harvesting } \\
\text { Damage during transport }\end{array}$ & 11.4 & 30 & 22.7 \\
Lack of market & 11.4 & 48.3 & 18.2 \\
Damage during packing & 2.3 & 20.7 & 27.3 \\
\hline Source Own Surve, 2015 & & 10.3 & 9.1
\end{tabular}

Source: Own Survey, 2015
Table 13 Proportion of value actors using different means to reduce spoilage (\%)

\begin{tabular}{|c|c|c|c|}
\hline $\begin{array}{l}\text { Practice to reduce } \\
\text { spoilage }\end{array}$ & $\begin{array}{l}\text { Producers } \\
(N=60)\end{array}$ & $\begin{array}{l}\text { Wholesaler } \\
(N=29)\end{array}$ & $\begin{array}{l}\text { Retailer } \\
(N=22) \\
\end{array}$ \\
\hline $\begin{array}{l}\text { Collect during cool } \\
\text { weather }\end{array}$ & 23.3 & 10.3 & 0 \\
\hline $\begin{array}{l}\text { Careful handling dur- } \\
\text { ing harvest }\end{array}$ & 48.3 & 34.5 & 18.75 \\
\hline Store under shade & 10.0 & 3.4 & 37.5 \\
\hline Store in a cool place & 1.7 & 17.2 & 12.5 \\
\hline $\begin{array}{l}\text { Take care during } \\
\text { transport }\end{array}$ & 6.7 & 31.0 & 6.25 \\
\hline $\begin{array}{l}\text { Use padding/cushion- } \\
\text { ing material during } \\
\text { transport }\end{array}$ & & - & 0 \\
\hline $\begin{array}{l}\text { Harvest after buyers } \\
\text { identified }\end{array}$ & 23.3 & & \\
\hline Sell at lower price & & 10.3 & 6.25 \\
\hline Nothing & 8.3 & 3.4 & 12.5 \\
\hline
\end{tabular}

Source: Own Survey, 2015

and identification of potential buyers before harvesting, while village collectors and wholesalers give due attention to better transportation infrastructure, and produce handling and management. Retailers on the other hand manage the situation through storing the produce under shade/cool areas. The FGDs and KIIs results indicate that produce cooling and storing under shade are insignificant in terms of addressing postharvest losses mainly because of limited capacities and access to necessary facilities and services. A recent report by [33] also indicates that farmers mainly sell vegetables immediately after harvesting as a means of reducing postharvest loss and costs associated with storage and transportation of such perishable fresh produce. Consequently, the information generated through this study has wide applications for other regions in Ethiopia.

\section{Summary and conclusions}

Significant postharvest losses occur along the tomato value chain with detrimental effects on the incomes of smallholder farmers and traders. About a quarter of tomato produced is damaged and puts out of normal use. The forms of damage include physical or mechanical damage, disease and/or insect pest infection, and/or poor shape, color and size of produce or combinations of these factors thereof. At farm level, postharvest loss is a continuum of disease and pest attack, lack of access to appropriate tools and skills during harvesting, poor postharvest handling and lack of market to sell the produce immediately after harvest. Postharvest loss which occurred at one value chain node extends to the other chain actors and also aggravates along the value chain 
due to poor handling, transporting, storage and ambient temperature which deteriorate the produce quality. Fresh produce handling and marketing facilities such as cooling facilities are lacking. To reduce the postharvest losses of tomato, serious interventions are needed, including skill building to improve preharvest crop management practices, capacity for postharvest handling including cool storage, improving market information, facilities and services.

\begin{abstract}
Abbreviations
EHDA: Ethiopian Horticulture Development Agency; FAO: Food and Agricultural Organization of the United Nations; FGD: focus group discussion; KII: key informant interview; USDA: United States Department of Agriculture; WFLO: World Food Logistics Organization; WorldVeg: World Vegetable Center.
\end{abstract}

\section{Authors' contributions}

$\mathrm{NN}$ and VA-S designed the research concept idea. NN, VA-S and -BE developed the data collection tools. AA, DK and HM participated in data collection with backstopping from BE as lead. BE led the data analysis and drafting of the manuscript. NN and VA-S contributed to review of data analysis, writing and proof reading of the paper. All authors read and approved the final manuscript.

\section{Authors' information}

Dr. Bezabih Emana is an Agricultural Economist and General Manager of HEDBEZ Business \& Consultancy PLC, an independent consulting firm in Addis Ababa, Ethiopia. Mr. Ngoni Nenguwo is a Postharvest Specialist and Technical Leader of the World Vegetable Center (WorldVeg)'s 5-year USAID-funded postharvest program (2012-2017) based in Arusha, Tanzania. Dr. Victor Afari-Sefa is an Agricultural Economist, Acting Regional Director, West and Central Africa \& Global Theme Leader - Consumption of WorldVeg and based in Bamako, Mali. Dr. Amsalu Ayana is a Seed Systems Specialist working as a Program Manager for the Integrated Seed System Development Program of Ethiopia funded by the Dutch government and an Associate of HEDBEZ Business \& Consultancy PLC. Dereje Kebede and Hedija Mohammed are both Research Associates of HEDBEZ Business \& Consultancy PLC, Addis Ababa, Ethiopia.

\section{Author details}

${ }^{1}$ HEDBEZ Business \& Consultancy PLC, P. O. Box 15805, Addis Ababa, Ethiopia. ${ }^{2}$ World Vegetable Center, West and Central Africa, Samanko Research Station, PB 320, Bamako, Mali. ${ }^{3}$ World Vegetable Center, Eastern and Southern Africa, P. O. Box 10, Duluti, Arusha, Tanzania.

\section{Acknowledgements}

The support for this research work was provided by the Bureau for Food Security, US Agency for International Development, under the terms of Award No. AID-BFS-IO-1200004 through: The World Vegetable Center, Eastern and Southern Africa in Arusha, Tanzania. The opinions expressed in this publication are those of the author(s) and do not necessarily reflect the views of the US Agency for International Development.

\section{Competing interests}

The authors declare that they have no competing interests. They have, of course, personal and professional interests in conducting baseline and impact assessment studies and innovations in postharvest handling and marketing of vegetable produce, the findings of such studies and success of applicable innovations in postharvest management for Ethiopia for food and nutrition security policy implications.

\section{Availability of supporting data}

The data sets supporting the results of this article are available upon request.

\section{Ethical approval and consent to participate}

Appropriate ethical clearance was sort verbally from the sector Ministry of Agriculture and local government authorities and respective communities prior to the study. All respondents who participated in the field study were duly informed about the purpose of the study and their right to decline participation in the study, and verbal consent was obtained from all participants prior to interviews.

\section{Funding}

Funding for this study was provided by the Bureau for Food Security of the US Agency for International Development, Washington, D.C., USA via the World Vegetable Center (WorldVeg).

Received: 24 July 2016 Accepted: 16 December 2016

Published online: 10 March 2017

\section{References}

1. Adeoye IB, Odeleye OMO, Babalola SO, Afolayan SO. Economic analysis of tomato losses in Ibadan Metropolis, Oyo State, Nigeria. Afr J Basic Appl Sci. 2009;1(5-6):87-92.

2. Adish A. Micronutrient deficiencies in Ethiopia: present situation and way forward. 2012. http://www.epseth.org/a/files/Micronutrient\%20Deficiencies\%20in\%20Ethiopia.pdf. Accessed 11 Nov 2014.

3. Aklilu S. Research achievement on variety development and seed production of vegetable crops in Ethiopia. In: Chadha ML, Altoveros EC, Nono-Womdim R, Mndiga H editors. AVRDC Africa Regional Program 2000. Varietal evaluation and seed production of vegetable crops held at AVRDC Africa Regional Program, Arusha, Tanzania, 29th September to 5th October 1997. Asian Vegetable Research and Development CenterAfrica regional Program, Arusha, Tanzania. AVRDC ARP Publication No. 2000-2; 2000; p. 6-11

4. Aramyan LH, van Gouh JB. Reducing postharvest food losses in developing economies by using a Network of Excellence as an intervention tool, paper presented at the 2014 IFAMA and CCA Food and Agribusiness World Forum 'People Feed the World' in Cape Town, South Africa, June 15-19; 2014.

5. Ayana A, Afari-Sefa V, Emana B, Dinssa FF, Balemi F, Temesgen M. Analysis of vegetable seed systems and implications for vegetable development in the Humid Tropics of Ethiopia. Int J Agric For. 2014;4(4):325-37.

6. Baredo Y. Gamo Gofa zone diagnosis and planning document, Livestock and Irrigation Value Chains for Ethiopian Smallholders (LIVES) project. Ethiopia: Addis Ababa; 2012.

7. EHDA, Ethiopian Horticulture Development Agency. Ethiopian Horticulture Sector Statistical Bulletin. Issue 01, Addis Ababa Ethiopia; 2012. Available online at: http://ehda.gov.et/Downloads/Statistical_Bulletin\%282012\%29.pdf. Accessed 17 Nov 2013.

8. Emana B, Gebremedhin H. Constraints and opportunities of horticulture production and marketing in eastern Ethiopia. DCG Report No. 46, Addis Ababa, Ethiopia; 2007.

9. Emana B, Afari-Sefa V, Dinssa FF, Ayana A, Balemi F, Temesgen M. Characterization and assessment of vegetable production and marketing systems in the Humid Tropics of Ethiopia. Q J Int Agric. 2015;54(2):163-85.

10. Ethiopian Investment Agency. Investment opportunity profile for production of fruits and vegetables in Ethiopia; 2012.

11. Etebu E, Nwauzoma AB, Bawo DDS. Postharvest spoilage of tomato (Lycopersicon esculentum Mill.) and control strategies in Nigeria. J Biol Agric Healthc. 2013;3(10):51-61.

12. Gebre E. An overview of horticultural crops with emphasis on vegetables production in Ethiopia, paper presented at Tuta Absoluta WorkshopMeeting the challenge of the tomato leaf miner, Nov 26-28, 2013, Intercontinental Hotel, Addis Ababa, Ethiopia; 2013.

13. Genanew T. Effect of post harvest treatments on storage behavior and quality of tomato fruits. World J Agric Sci. 2013;9(1):29-37.

14. Getinet $\mathrm{H}$, Workneh TS, Woldetsadik K. Effect of maturity stages, variety and storage environment on sugar content of tomato stored in multiple pads evaporative cooler. Afr J Biotechnol. 2011;10(80):18481-92.

15. FAO. Role of agro-industry in reducing food losses in the middle East and North Africa region; 2012.

16. Hussen S, Beshir H, Yitbarek Woldehawariyat Y. Postharvest loss assessment of commercial horticultural crops in South Wollo, Ethiopia "Challenges and Opportunities". Food Sci Qual Manag. 2013;17:34-9. 
17. Helvetas. Consequences of post-harvest losses to vegetable farmers in Tanzania: a case of Singida region. HELVETAS Swiss Intercooperation Survey Report 2014. 2014; p. 32.

18. Kader AA. A perspective on postharvest horticulture (1978-2003). HortSciience. 2003;38(5):1004-8.

19. Kader AA. Increasing food availability by reducing postharvest losses of fresh produce. In: Proceedings of 5th international Postharvest symposium. Acta Hort 682, 2169-78; 2005.

20. Kader AA. The return on investment in postharvest technology for assuring quality and safety of horticultural crops. J Agric Invest. 2006;4:45-52.

21. Kahsay Y, Abay F, Belew D. Intra row spacing effect on shelf life of onion varieties (Allium cepa L.) at Aksum, northern Ethiopia. World J Agric Res Food Saf. 2013;1 (2):34-42.

22. Kaminski J, Christiaensen L. Post-harvest loss in Sub-Saharan AfricaWhat Do Farmers Say? Policy Research Working Paper 6831, World Bank: 2014.

23. Kitinoja L. Identification of appropriate postharvest technologies for improving market access and incomes for small horticultural farmers in sub-Saharan Africa and south Asia. WFLO Grant Final Report, 2010; p. 323.

24. Kitinoja L, AlHassan HY. Identification of appropriate postharvest technologies for small scale horticultural farmers and marketers in Sub-Saharan Africa and South Asia: Part 1. Postharvest losses and quality assessments. Acta Hort. 2012;934:31-40.

25. Negasi TA, Nigussie DR, Kebede W, Lemma D, Abuhay T. Characterization of soil nutrient management and postharvest handling practices for onion production in the Central Rift Valley region of Ethiopia. Agric For Fish. 2013;2(5):184-95.

26. Olayemi FF, Adegbola JA, Bamishaiye EI, Daura AM. Assessment of postharvest challenges of small scale farm holders of tomatoes, bell and hot pepper in some local government areas of Kano State, Nigeria. Bayero J Pure Appl Sci. 2010;3(2):39-42.

27. Parfitt J, Barthel M, Macnaughton S. Food waste within food supply chains: quantification and potential for change to 2050. Philos Trans R Soc. 2010;365:3065-81.

28. Prigojin I, Fallik E, Qat Y, Ajalin I, Allam H, Ezzat M, Bader M. Middle East regional agricultural program: survey on postharvest losses of tomato fruit and table grapes. In: Proceedings of the 5th international postharvest symposium, June 6-11 in Verona, Italy. Acta horticulture; 2005.
29. Tabor G, Yesuf M. Mapping the current knowledge of carrot cultivation in Ethiopia. Charlottenlund: Technical Report Submitted to Carrot Aid; 2012.

30. Tadesse F. Postharvest losses of fruits and vegetables. J Hortic. 1991;270:261-70.

31. Teka TA. Analysis of the effect of maturity stage on the postharvest biochemical quality characteristics of tomato (Lycopersicon esculentum MILL.) fruit. Int Res J Pharm Appl Sci. 2013;3(5):180-6.

32. Ukech JA, Chiejina NV. Preliminary investigations of the cause of postharvest fungal rot of tomato. IOSR J Pharm Biol Sci. 2012;4(5):36-9.

33. USAID. Cost-benefit analysis of the potatoes, onions, and tomatoes value chains in Ethiopia: graduation with resilience to achieve sustainable development (GRAD) project final report; 2013.

34. USDA. The commercial storage of fruits, vegetables and nursery stocks; 2004. Agric. Handbook 66. http://www.ba.ars.usda.gov/hb66/contents. html. Accessed 2 April 2014.

35. WFLO, World Food Logistics Organization. Identification of appropriate postharvest technologies for improving market access and incomes for small horticultural farmers in Sub-Saharan Africa and South Asia. 2010; WFLO Grant Final Report, University of California, UC, Davis, USA.

36. Workneh TS. Feasibility and economic evaluation of low-cost evaporative cooling system in fruit and vegetables storage. Afr J Food Agric Nutr Dev. 2010;10(8):2984-97.

37. Workneh TS, Osthoff G, Steyn MS. Preharvest treatment, disinfections and storage environment on quality of tomato. J Food Sci Technol. 2011. doi:10.1007/s13197-011-0391-3.

38. Workneh TS, Osthoff G, Steyn MS. Influence of pre-harvest and postharvest treatments on stored tomato quality. Afr J Agric Res. 2011;6(12):2725-36.

39. Workneh TS, Osthoff G, Steyn MS. Physiological and chemical quality of carrots subjected to pre-and postharvest treatments. Afr J Agric Res. 2011:6(12):2715-24

40. Workneh TS, Woldetsadik K. Forced ventilation evaporative cooling: a case study on banana, papaya, orange, mandarin, and lemon. Trop Agric. 2004;81(3):179-85.

\section{Submit your next manuscript to BioMed Central and we will help you at every step:}

- We accept pre-submission inquiries

- Our selector tool helps you to find the most relevant journal

- We provide round the clock customer support

- Convenient online submission

- Thorough peer review

- Inclusion in PubMed and all major indexing services

- Maximum visibility for your research

Submit your manuscript at www.biomedcentral.com/submit 